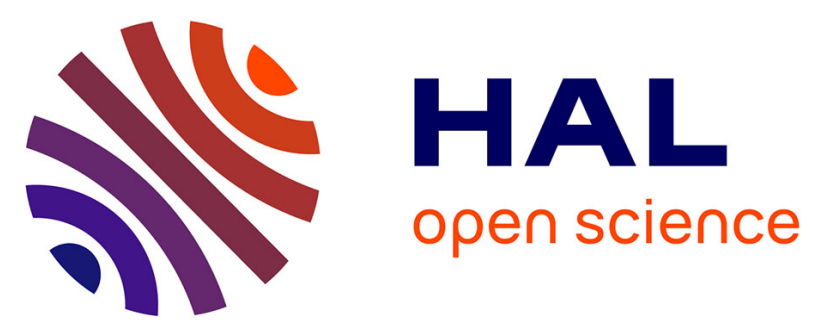

\title{
Manioc peel and charcoal: a potential organic amendment for sustainable soil fertility in the tropics
}

Stéphanie Topoliantz, Jean-François Ponge, Sylvain Ballof

\section{To cite this version:}

Stéphanie Topoliantz, Jean-François Ponge, Sylvain Ballof. Manioc peel and charcoal: a potential organic amendment for sustainable soil fertility in the tropics. Biology and Fertility of Soils, 2005, 41 (1), pp.15-21. 10.1007/s00374-004-0804-9 . hal-00496997

\section{HAL Id: hal-00496997 https://hal.science/hal-00496997}

Submitted on 2 Jul 2010

HAL is a multi-disciplinary open access archive for the deposit and dissemination of scientific research documents, whether they are published or not. The documents may come from teaching and research institutions in France or abroad, or from public or private research centers.
L'archive ouverte pluridisciplinaire HAL, est destinée au dépôt et à la diffusion de documents scientifiques de niveau recherche, publiés ou non, émanant des établissements d'enseignement et de recherche français ou étrangers, des laboratoires publics ou privés. 
1 Manioc peel and charcoal: a potential organic amendment for sustainable soil

2 fertility in the tropics

3

4

5 Stéphanie Topoliantz ${ }^{1}$, Jean-François Ponge ${ }^{1}$, Sylvain Ballof ${ }^{2}$

6

7

$8{ }^{1}$ Museum National d'Histoire Naturelle, CNRS UMR 5176, 4 avenue du Petit-Château,

991800 Brunoy, France

10 2Office National des Forêts, BP 9, 97370 Maripasoula, Guyane française

11

12 Corresponding author: Jean-François Ponge, tel. +33 1 60479213, fax +33 1

13 60465009; E-mail: jean-francois.ponge@wanadoo.fr

14

15 


\section{Abstract}

3 In tropical areas, where crop production is limited by low soil quality, the development

4 of techniques improving soil fertility without damage to the environment is a priority. In

5 French Guiana, we used subsistance farmer plots on poor acidic soils to test the effect

6 of different organic amendments, bitter manioc peel (M), sawdust (Sw) and charcoal

7 (Ch), on soil nutrient content, earthworm abundance and yard-long bean (Vigna

8 unguiculata sesquipedalis) production. The peregrine Pontoscolex corethrurus was the

9 only earthworm species found. Pod production and plant growth were lowest in 10 unamended soil. The application of a mixture of manioc peel and charcoal $(\mathrm{M}+\mathrm{Ch})$ 11 improved legume production as compared with other organic mixtures. It combined 12 favourable effects of manioc peel and charcoal. Manioc peel improved soil fertility 13 through its low $\mathrm{C}: \mathrm{N}$ ratio and its high $\mathrm{P}$ content, while charcoal decreased soil acidity 14 and exchangeable $\mathrm{Al}$ and increased $\mathrm{Ca}$ and $\mathrm{Mg}$ availability, thus alleviating possible 15 toxic effects of $\mathrm{Al}$ on plant growth. The $\mathrm{M}+\mathrm{Ch}$ treatment was favourable to $P$. 16 corethrurus, the juvenile population of which reaching a size comparable to that of the 17 nearby uncultivated soil. The application of a mixture of manioc peel and charcoal, by 18 improving crop production and soil fertility and enhancing earthworm activity, could be 19 a potentially efficient organic manure for legume production in tropical areas where 20 manioc is cultivated under slash-and-burn shifting agriculture.

22 Key-words Organic farming, Slash-and-burn cultivation, Aluminum, Phosphorus, 23 Earthworm density, Legume, Soil nutrient content

Introduction

27 In the tropics, traditional shifting cultivation still supplies food to 300-500 million families 28 (Anonymous 1985). However, in some areas, under increasing population pressure 
1 and lack of cultivable land, usually farmers shorten the fallow period (Seiler and

2 Crutzen 1980; Brady 1996). Biological soil functioning is rapidly perturbed when the

3 balance between plant needs, nutrient availability and decomposer activity is disrupted

4 by the shift from traditional slash-and-burn agriculture towards permanent cultivation

5 (Myers and De Pauw 1995; Lavelle 1997). Without cheap, reliable techniques to

6 maintain the fertility of acid soils under permanent cultivation, crop production rapidly

7 decreases and poverty increases among farmers.

8

Considering the cost of inorganic, synthetic fertilisers for poor local farmers, and significant leaching losses in sandy soils poor in organic matter, new fertilising techniques in the tropics increasingly rely on the management of soil biota, a key factor in soil fertility (Lavelle et al. 1989; Beare et al. 1997). Methods using green waste and soil fauna activity were developed to improve crop production by stabilising nutrients and organic matter within soil biogenic structures (Sparovek 1998; Senapati et al. 1999).

Senapati et al. (1999) improved tomato production in Peru with composted sawdust, reaching the same level as with inorganic fertilizers. Several studies, reviewed by Glaser et al. (2002), showed that charcoal, through its positive effects on soil physical and chemical properties, can improve microbial activity and crop production. In the presence of the endogeic earthworm Pontoscolex corethrurus (Glossoscolecidae, Oligochaeta), a species adapted to tropical cultivated soils (Lavelle et al. 1987), we previously found that yard-long bean (Vigna unguiculata sesquipedalis L.) production was improved by amendment with manioc peel and to a lesser extent by charcoal. These two amendments, respectively, increased $\mathrm{P}$ availability and decreased soil acidity (Topoliantz, unpublished doctorate thesis). In Latin America and Africa, bitter manioc (Manihot esculenta ultilissima Crantz) is widely cultivated for its tubers (Guillaumet 1996), and their peel, produced in large quantity, provides a potentially 
1 valuable green waste that can be used for vermicomposting despite its cyanide toxicity

2 (Mba 1983, 1996).

3

4

Tian et al. (1997) found that combining mulches of different quality could help to

5 synchronize nutrient supply with plant needs. The goal of our present study was to test

6 the combined effects of manioc peel, charcoal and sawdust on yard-long bean

7 production, in the true conditions of subsistance farming. Considering the whole

8 agroecosystem plant-soil-fauna, we also determined how mulches affected the soil

9 nutrient content and the earthworm populations as compared with unamended soil. The

10 trial was carried out in the local farming context in order to provide new cheap solutions

11 to improve crop yields in the tropics.

12

13 Materials and methods

14

15

Site and soil amendment

16

17 The experimental study was conducted in French Guiana at Maripasoula $\left(3^{\circ} 39^{\prime} \mathrm{N}\right.$; $1854^{\circ} 2^{\prime} \mathrm{W}$ ) in a local farmer's field (Topoliantz et al. 2002). The soil was an Oxisol with $1958 \%$ sand, $14 \%$ silt, $24 \%$ clay, and $3 \%$ organic matter in the top $10 \mathrm{~cm}$. Soil 20 preparation for legume culture was carried out according to local practices. In April 212001 the natural herb layer was cut and the soil was hoe-harrowed to $20 \mathrm{~cm}$ depth. At 22 the soil surface, rows of different organic mixtures composed of weakly composted 23 manioc peel $(\mathrm{M})$, local home-made charcoal $(\mathrm{Ch})$ and fresh sawdust from a local 24 sawyer $(\mathrm{Sw})$ were applied at the rate of $100 \mathrm{~L}$ per row $\left(67 \mathrm{~L} . \mathrm{m}^{-2}\right)$. The chemical 25 composition of $\mathrm{M}, \mathrm{Ch}$ and $\mathrm{Sw}$ is presented in Table 1. Equal volumes of organic wastes were mixed together and were covered with soil to form mounds, as in traditional

27 practice. There were four mounds amended with $M+C h, M+S w, C h+S w$, and $28 \mathrm{M}+\mathrm{Ch}+\mathrm{Sw}$ and a control mound made of non-amended soil (NoA), each $25 \mathrm{~cm}$ wide 
1 and $6 \mathrm{~m}$ long, placed at $1 \mathrm{~m}$ distance from each other, parallel to the gentle land slope.

2 Lack of space and allowance for traditional methods of cultivation prevented us to

3 impose a randomized block design on the local farmer who kindly accepted to perform

4 the experiment on his own land.

5

6 Crop production and plant sampling

7

8 Four months after incorporating organic mixtures to the soil, i.e. in October 2001, seeds

9 of yard-long bean ( $V$. unguiculata sesquipedalis) were sowed in the mounds, with pairs

10 of seeds in holes about $40 \mathrm{~cm}$ apart. Two months later, i.e. in December 2001, plants

11 were harvested by hand, paying attention to the root system, and the survival rate was

12 measured. Aerial parts were separated from root systems, shoots were dried in

13 newspaper and root systems were preserved in ethyl alcohol until laboratory analysis.

14 Legume nodules were isolated from roots, then all plant parts (shoots, pods, roots and

15 nodules) were dried at $105^{\circ} \mathrm{C}$ and weighed. Aphids present on root systems were 16 collected from the fixative and counted.

18 Earthworm sampling

20 Earthworms were sampled in the mounds at the time of crop harvesting (December 21 2001) according to the TSBF method (Anderson and Ingram 1993). Four soil blocks 25 $22 \mathrm{~cm} \times 25 \mathrm{~cm} \times 30 \mathrm{~cm}$ were collected $2 \mathrm{~m}$ apart on the ridge of each mound, thus 23 totalling 20 samples. Earthworm individuals and cocoons were sorted by hand and 24 counted. Earthworms were also sampled with the same method under adjacent 25 uncultivated herb vegetation. Twelve samples were taken in four rows three-meter long $2690 \mathrm{~cm}$ apart. All earthworm individuals were identified as $P$. corethrurus. They were 
1 sorted according to their size, as juveniles (newly hatched individuals) and adults

2 (clitellate as well as non clitellate) before being replaced in the soil.

$4 \quad$ Soil sampling and analyses

6 In the gaps between the five mounds, a total of eighteen $(4 \times 4)$ soil samples were

7 taken for determining the composition of the original soil at the time of soil preparation

8 (April) and checking for gradients of soil fertility in the experimental field (Table 2). At

9 the time of harvest (December) eleven soil blocks per experimental mound, each $7 \mathrm{~cm}$

$10 \times 7 \mathrm{~cm}$ area from $0-10 \mathrm{~cm}$ depth, were collected at different places of the ridges, thus

11 totalling 55 samples. The soil was air-dried before transport to the laboratory for

12 chemical analyses: organic C and N according to ISO 10694 and 13878, respectively

13 (Anonymous 1999), soil acidity $\left(\mathrm{pH}_{\text {water }}\right.$ and $\left.\mathrm{pH}_{\mathrm{kcl}}\right)$, total $\mathrm{P}\left(\mathrm{P}_{\text {tot }}\right)$ and available $\mathrm{P}\left(\mathrm{P}_{\mathrm{av}}\right.$,

14 Olsen method), total $\mathrm{K}\left(\mathrm{K}_{\mathrm{tot}}\right)$, cation exchange capacity (hexamine cobalt extraction), 15 exchangeable $\mathrm{K}\left(\mathrm{K}_{\mathrm{ex}}\right), \mathrm{Mg}\left(\mathrm{Mg}_{\mathrm{ex}}\right)$, $\mathrm{Ca}\left(\mathrm{Ca}_{\mathrm{ex}}\right), \mathrm{Na}\left(\mathrm{Na}_{\mathrm{ex}}\right)$ and $\mathrm{Al}\left(\mathrm{Al}_{\mathrm{ex}}\right)$ according to Baize 16 (2000). The base saturation of the sorption complex (S/CEC, S=sum of exchangeable $17 \mathrm{~K}, \mathrm{Mg}, \mathrm{Ca}$ and $\mathrm{Na}$ ) was calculated. Cyanide contents were measured according to NF 18 T90-107 (Anonymous 2001) in soil samples as well as in three samples of weakly 19 composted manioc peel which had been dried for $48 \mathrm{~h}$ at $105^{\circ} \mathrm{C}$.

21 Statistical analysis

22

23 Crop, earthworm and soil chemical data were statistically analysed (Glantz, 1997). 24 Differences between rows (six) and slope positions (three) in chemical properties of the 25 original soil were tested by two-way ANOVA without replication. The effects of treatments $(\mathrm{M}+\mathrm{Ch}, \mathrm{M}+\mathrm{Sw}, \mathrm{Ch}+\mathrm{Sw}, \mathrm{M}+\mathrm{Ch}+\mathrm{Sw}$ and $\mathrm{NoA})$ on crop, earthworm and soil

27 data were tested by one-way ANOVA (data were log-transformed when necessary) or 28 Kruskall-Wallis rank tests when assumptions of ANOVA were not fully satisfied even 
1 after log transformation. Multiple comparisons among means or between groups were 2 done a posteriori using Tukey's test or Dunn's test following ANOVA or Kruskall-Wallis 3 rank test, respectively. The effect of treatments on plant survival was tested by $\chi^{2}$. 4 Relationships between nodules, pods, shoot, root and aphids were tested by 5 Spearman rank correlation coefficients. Comparisons of cocoon and earthworm 6 abundances between natural fallow and other treatments were made using Dunnett's 7 method. The chemical composition of the initial soil (between mounds) and that of the 8 non-amended mound (NoA) were compared by t-test.

Results

12 There were no detectable differences between the six rows (four rows between 13 mounds and two outside) in the 15 soil parameters which were measured on the initial 14 (uncultivated) soil (Table 2). Only two out of 15 parameters showed a (weak, although significant at $\mathrm{P} 0.05$ level) slope effect: the $\mathrm{P}$ content decreased from 198 to 160 $\mathrm{mg} \cdot \mathrm{kg}^{-1}$ from up- to downslope and the base saturation was maximum downslope $17(67 \%)$ and minimum at mid slope (48\%). Given the absence of differences between rows and because replication was achieved along the slope within each treatment, we considered that treatments effects were not biased by spatial heterogeneity, despite the absence of block design.

The survival rate of bean (number of shoots living at the time of harvest against number of seeds planted) was only weakly affected by treatments $\left(\chi^{2}=9.38, P=0.052\right)$, although in NoA the observed survival rate was higher than in other treatments. Pod production (per shoot) was higher in $\mathrm{M}+\mathrm{Ch}$ than in $\mathrm{Ch}+\mathrm{Sw}$ and $\mathrm{NoA}$ treatments where it was nil or near nil (Fig. 1). The effects of treatments on other plant parameters are

27 presented in Table 3. The dry weight of shoots and the shoot:root ratio were higher in 28 the presence of amendments $(M+C h, M+S w, C h+S w, M+C h+S w)$ but did not differ 
1 among amendments. The shoot:nodule ratio was higher in $\mathrm{M}+\mathrm{Ch}$ than in NoA and the

2 root:nodule ratio was not affected by treatments.

3

4

Aphid density (number of individuals per $\mathrm{g}$ of dry root, 4.2 in average) was not

5 affected by treatments $(\mathrm{H}=0.574, \mathrm{P}=0.97)$.

6

Figure 2 shows the distribution of cocoons, juvenile and adult/subadult $P$. corethrurus under each treatment and the natural fallow, at the time of harvest (December). As a consequence of cultivation, a decrease was observed in juvenile densities compared to the natural fallow, except under $M+C h$ amendment. Only $M+S w$ decreased cocoon densities compared to the natural fallow. No general decrease and no differential effect of treatments was observed in the adult/subadult population.

At the time of harvest, all soil nutrients except $\mathrm{Na}$ were significantly influenced by treatments (Table 4). A higher $\mathrm{pH}_{\text {water }}$ was found in treatments using charcoal $(\mathrm{M}+\mathrm{Ch}, \mathrm{M}+\mathrm{Ch}+\mathrm{Sw}$ and $\mathrm{Ch}+\mathrm{Sw})$ and the highest $\mathrm{pH}_{\mathrm{KCl}}$ was observed in the $\mathrm{M}+\mathrm{Ch}$ treatment. Whatever the method used to measure $\mathrm{pH}$, NoA was the most acidic. The $\mathrm{C}: \mathrm{N}$ ratio was highest in amendments containing sawdust $(\mathrm{M}+\mathrm{Sw}, \mathrm{Ch}+\mathrm{Sw}, \mathrm{M}+\mathrm{Ch}+\mathrm{Sw})$. Cation Exchange Capacity (CEC) was lowest in $\mathrm{Sw}+\mathrm{Ch}$ and $\mathrm{M}+\mathrm{Sw}+\mathrm{Ch}$ treatments and highest in NoA. In this latter treatment, we found the highest rate of exchangeable Al and the lowest rate of exchangeable $\mathrm{Mg}, \mathrm{Ca}$ and base saturation, the reverse being observed in the $\mathrm{M}+\mathrm{Ch}$ treatment.

When compared to the composition of the original soil (Table 1), NoA exhibited a lower $\mathrm{C}: \mathrm{N}$ ratio $(\mathrm{t}=4.7, \mathrm{P}<0.001), \mathrm{pH}$ Water $(\mathrm{t}=5, \mathrm{P}<0.001)$ and $\mathrm{pH} \mathrm{KCl}(\mathrm{t}=3.5, \mathrm{P}=$ 0.001) and a higher exchangeable Al level ( $t=-3.7, P<0.001)$. Most cyanide levels

27 were below the detection limit $\left(<0.1 \mathrm{mg} \cdot \mathrm{kg}^{-1}\right)$ except for three samples in the $\mathrm{M}+\mathrm{Sw}+\mathrm{Ch}$ 
1 treatment which showed a very low cyanide content $\left(0.11,0.11\right.$ and $\left.0.12 \mathrm{mg} \cdot \mathrm{kg}^{-1}\right)$ as 2 compared with manioc peel $\left(3.6 \mathrm{mg} \cdot \mathrm{kg}^{-1}\right)$.

\section{Discussion}

6 The development of aerial parts of $V$. unguiculata sesquipedalis $L$. was improved by 7 amending mixtures as compared with non-amended soil. When nutrients are scarce, 8 plants develop their root system at the expense of shoot growth (Taiz and Zeiger 9 1998). Nodulation was reduced by amendment, suggesting a poorer mineral $\mathrm{N}$ availability in the unamended soil (Salisbury and Ross 1985). In the absence of amendment we also observed a higher soil acidity compared with amended as well as initial soil. A high level of $\mathrm{Al}$, often observed at low $\mathrm{pH}$ in the soil solution (Nair and Prenzel 1978), may be detrimental to cultivated plants by reducing root growth and uptake of P, Mg and Ca by roots (Foy 1974). The amendments did not exert any depressive effect on aphids, confirming that in this trial these sucking insects drain the sap flow without affecting plant growth (Salisbury and Ross 1985).

Pod production was highest in treatments with manioc peel, especially when supplemented with charcoal rather than sawdust. This result confirmed those obtained in our previous bioassay (Topoliantz et al. 2002), in which manioc peel amendment alone was the most productive treatment compared with charcoal, sawdust and nonamended soil. We attribute the beneficial effect of manioc peel to a higher $P$ availability, the effect being reinforced in the presence of $P$. corethrurus, which stimulates the mineralisation of microbial P (Barois et al. 1987; Brown 1995). Phosphorus and $\mathrm{K}$ levels in manioc peel were estimated to $2.26 \mathrm{~g} \mathrm{~kg}^{-1}$ and $10.3 \mathrm{~g} \mathrm{~kg}^{-1}$, respectively, thus higher than in charcoal $\left(0.268 \mathrm{~g} \mathrm{~kg}^{-1}\right.$ and $\left.5.05 \mathrm{~g} \mathrm{~kg}^{-1}\right)$ and far higher

27 than in sawdust $\left(0.0633 \mathrm{~g} \mathrm{~kg}^{-1}\right.$ and $\left.0.347 \mathrm{~g} \mathrm{~kg}^{-1}\right)$. However, at harvest time we did not 28 detect any increase in available $P$ in the soil under manioc peel, except when manioc 
1 peel were added together with charcoal and sawdust (Table 4). Given that pod 2 production was maximized under manioc peel amendment (Table 3 ) and that soil 3 collection for chemical analyses (Table 4) was done at harvest, we cannot discard that 4 at least part of the added $\mathrm{P}\left(38 \mathrm{~g} \cdot \mathrm{m}^{-2}\right)$ was mineralized then taken up by crop plants, 5 thus could not be detected in the soil. The negative effect of sawdust on pod production 6 (Table 3) could be due to $\mathrm{N}$ immobilization, which has been repeatedly reported to 7 occur in decaying wood (Swift 1977; Edmonds 1987).

At the time of harvest Al availability in the soil was lowest in the presence of a mixture of manioc peel and charcoal (Table 4). Charcoal, by increasing $\mathrm{pH}$, diminishes mobile forms of Al (Tan 1982). We found that the soil amended with charcoal presented also higher levels of exchangeable $\mathrm{Ca}$ and $\mathrm{Mg}$. Several studies previously showed that charcoal as well as its ashes increase the availability of $\mathrm{P}, \mathrm{K}, \mathrm{Mg}$ and $\mathrm{Ca}$ and decrease that of toxic elements such as heavy metals (Fe, Mn and $\mathrm{Zn}$ ) (Tryon 1948; Kishimoto and Sugiura 1985; Voundi Nkana et al. 1998). This effect can be attributed to the porous nature of charcoal, rather than to a liming effect, given its scarcity in nutrients when compared to manioc peel (Table 1). Charcoal exhibits a high internal surface (Carcaillet and Thinon 1996) which increases in the course of time and becomes progressively oxidised (Chan et al. 1999). Once chemically activated, charcoal acts as a filter and retains positively as well as negatively charged mineral ions in an exchangeable form (Holl and Horst 1997). Kishimoto and Sugiura (1985) showed that charcoal also improved soil porosity and moisture holding capacity, which led to better plant and root growth. In our study, lower soil acidity and toxic metals and higher rate of macro-nutrients were observed when charcoal was combined with manioc peel (with a high phosphorus content); this led also to better plant growth. We suspect a synergistic effect of these two amendments due to the high surface area of

27 charcoal that confers a high sorptive capacity for chemical compounds (Titoff 1910; 28 Zackrisson et al. 1996; Wardle et al. 1998) and microbial communities (Pietikaïnen et 
1 al. 2000). Given the low content of swelling clays and organic matter in tropical Oxisols

2 (Brady and Weil 1999), the existence of a stable, solid component with strong sorptive 3 properties, such as charcoal (Skjemstad et al. 1996), would help to retain mineral 4 nutrients liberated during the decomposition of organic amendments.

5

6

7

In contrast, soils from treatments with a mixture of manioc and sawdust exhibited at harvest the lowest $\mathrm{pH}$ and the same low base saturation as the complete mixture of manioc, sawdust and charcoal. Thus the addition of sawdust to a mixture of manioc and charcoal did not provide any benefit to legume production, even suggesting a negative effect of the three amendments when combined. Fresh sawdust is not palatable to saprophagous biota because of its low nutrient and high phenolic content (Tian et al. 1993). Thus the addition of non-composted sawdust may inhibit manioc peel decomposition. It seems that the positive effect of sawdust amendment on soil nutrient content may appear later than that of manioc peel because of much slower decomposition.

Only the mixture of manioc and charcoal did not depress earthworm densities. In the natural fallow, $P$. corethrurus juveniles and cocoons were mostly present in the upper $20 \mathrm{~cm}$ of the soil and adults tended to live more deeply (Topoliantz, unpublished doctorate thesis). Fragoso (1985) already observed the same vertical distribution of $P$. corethrurus during the dry season. Under cultivation, adults and juveniles were mostly present at greater depths than in the fallow (Topoliantz, unpublished doctorate thesis), suggesting some avoidance effect of mounded soil, which was lessened under mixed manioc-charcoal amendment. Presumably earthworms burrowed deeper in order to avoid desiccation of the superficial soil layers, especially in non-amended cultivated soil. The manioc-charcoal mixture presented as many cocoons and juveniles as the natural fallow, indicating that this amendment did not interfere with $P$. corethrurus reproduction. 
The cyanide content of our manioc peel was very low (3.6 mg. $\left.\mathrm{kg}^{-1}\right)$ compared

3 with that reported by Mba (1983) in decomposed peel (168.5 mg.kg ${ }^{-1}$ ). Thus in our

4 study this amendment did not produce cyanide toxicity in the soil. We also observed

5 that soil aggregates $0.2-0.6 \mathrm{~cm}$ (mostly earthworm faeces) were negatively correlated

6 with soil acidity (Topoliantz, unpublished doctorate thesis), indicating that charcoal,

7 which increased $\mathrm{pH}$, favoured juvenile earthworm activity. Although $P$. corethrurus is

8 known to tolerate soil acidity (Lavelle et al. 1987), juveniles are apparently more

9 sensitive to this factor, and thus any treatment increasing $\mathrm{pH}$ will favour this peregrine

10 species which is able to ingest charcoal and mix it with the original soil (Topoliantz and

11 Ponge 2003).

12

Under conditions that can be managed by subsistance farmers the combination

14 of charcoal and manioc peel offers a cheap, reliable method to alleviate Al toxicity and 15 to increase the nutrient status of acid tropical soils, through the buffer and filter power 16 of charcoal and the input of $\mathrm{P}$ by manioc, thus improving legume production. It also 17 provides favourable conditions for earthworm reproduction, allowing the maintainence 18 of the fragile equilibrium between producers (plants) and decomposers (microbes, soil 19 fauna) under tropical agriculture. As manioc peel are rapidly decomposed by soil biota, 20 this amendment will have to be regularly added, whereas charcoal does not need to be 21 supply repeatedly, being persistent in the soil (Glaser et al. 2001). Farther, excess of 22 charcoal could even depress plant growth due to a too high alkalinity (Kishimoto and 23 Sugiura 1985).

\section{Acknowledgements}

27 We thank the Mission pour la Création du Parc du Sud de la Guyane, the PPF-Guyane 28 of the Museum National d'Histoire Naturelle and the GIS-Silvolab of French Guiana for 
1 financial support and commodities. We are grateful to Mr Lobbini and his son, local

2 farmers, for their technical assistance on the field. We also thank the Institut Pasteur

3 (Lille, France) for cyanide analyses and the Institut National de la Recherche

4 Agronomique (Arras, France) for mineral soil analyses.

5

6 References

7

8 Anonymous (1985) Tropical Forestry Action Plan. FAO, Rome

9 Anonymous (1999) Qualité des sols. AFNOR, Paris

Anonymous (2001) Qualité de l'eau. AFNOR, Paris

Anderson JM, Ingram J (1993) Tropical Soil Biology and Fertility. A handbook of methods, $2^{\text {nd }}$ ed. CAB, Oxford

Baize D (2000) Guide des analyses en pédologie, $2^{\text {nd }}$ ed. INRA, Paris

14 Barois I, Verdier B, Kaiser P, Mariotti A, Rangel P, Lavelle P (1987) Influence of the tropical earthworm Pontoscolex corethrurus (Glossoscolecidae) on the fixation and mineralization of nitrogen. In: Bonvicini Pagliai AM, Omodeo P (eds) On earthworms, vol. 2. Mucchi, Modena, pp 151-158

Beare MH, Vikram Reddy M, Tian G, Srivastava SC (1997) Agricultural intensification, soil biodiversity and agroecosystem function in the tropics: the role of decomposer biota. Appl Soil Ecol 6: 87-108

Brady NC (1996) Alternatives to slash-and-burn agriculture: a global imperative. Agr Ecosyst Environ 58: 3-11

Brady NC, Weil RR (1999) The nature and properties of soils. Prentice-Hall, Upper Saddle River

Brown GG (1995) How do earthworms affect microflora and faunal community diversity? In: Collins HP, Robertson GP, Klug MJ (eds) The significance and regulation of soil biodiversity. Kluwer Academic Publishers, Dordrecht, pp 247- 
1 Carcaillet C, Thinon M (1996) Pedoanthracological contribution to the study of the evolution of the upper treeline in the Maurienne Valley (North French Alps): methodology and preliminary data. Rev Palaeobot Palynol 91: 399-416

Chan ML, Jones JM, Pourkashanian M, Williams A (1999) Oxidative reactivity of coal chars in relation to their structure. Fuel 78: 1539-1552

Edmonds RL (1987) Decomposition rates and nutirent dynamics in small-diameter woody litter in four forest ecosystems in Washington, U.S.A. Can J For Res 17: 499-509

Foy CD (1974) Effects of aluminium on plant growth. In: Carson EW (ed) The plant root and its environment. Virginia University Press, Charlottesville, pp 601-642

Fragoso C (1985) Ecologia general de las lombrices terrestres (Oligochaeta: Annelida) de la region Boca del Chajul, Selva Lancandona, Estado de Chapias. Unpublished doctorate thesis, Universidad Nacional Autonoma de Mexico, Mexico

Glantz SA (1997) Primer of biostatistics, $4^{\text {th }}$ ed. McGraw-Hill, New York

Glaser B, Haumaier L, Guggenberger G, Zech W (2001) The 'Terra Preta' phenomenon: a model for sustainable agriculture in the humid tropics. Naturwissenschaften 88: 37-41

Glaser B, Lehmann J, Zech W, (2002) Ameliorating physical and chemical properties of highly weathered soils in the tropics with charcoal: a review. Biol Fertil Soils 35: $219-230$

Guillaumet JL (1996) Les plantes alimentaires des forêts humides intertropicales et leur domestication: exemple africains et américains. In: Hladik CM, Hladik A, Pagezy H, Linares OF, Koppert GJA, Froment A (eds) L'alimentation en forêt tropicale: intéractions bioculturelles et perspectives de développement. UNESCO, Paris, pp 121-130

Holl WH, Horst J (1997) Description of sorption equilibria for ions onto activated barbon using the surface complexation theory. Water Sci Technol 35: 287-294 
1 Kishimoto S, Sugiura G (1985) Charcoal as soil conditioner. Int Achieve Future 5: 12-

2

3

4

5

6

7 23

Lavelle P (1997) Faunal activities and soil processes: adaptive strategies that determine ecosystem function. Adv Ecol Res 27: 93-132

Lavelle P, Barois I, Cruz I, Fragoso C, Hernandez A, Pineda A, Rangel P (1987) Adaptive strategies of Pontoscolex corethrurus (Glossoscolecidae, Oligochaeta), a peregrine geophagous earthworm of the humid tropics. Biol Fertil Soils 5: 188-194

Lavelle P, Barois I, Martin A, Zaidi Z, Schaefer R (1989) Management of earthworm populations in agro-ecosystems: a possible way to maintain soil quality? In: Clarholm M, Bergström L (eds) Ecology of arable land. Kluwer, Dordrecht, pp $109-122$

Mba CC (1983) Utilization of Eudrilus eugeniae for disposal of cassava peel. In: Satchell JE (eds) Earthworm ecology, from Darwin to vermiculture. Chapman and Hall, London, pp 315-321

Mba CC (1996) Treated cassava peel vermicomposts enhanced earthworm activities and cowpea growth in field plots. Resources Conserv Recycl 17: 219-226

Myers RJK, De Pauw E (1995) Strategies for management of soil acidity. In: Date RA, Grundon NJ, Rayment GE, Probert ME (eds) Plant-soil interactions at low pH: principles and management. Kluwer, Dordrecht, pp 729-741

Nair VD, Prenzel J (1978) Calculations of equilibrium concentration of mono- and polynuclear hydroxyaluminium species at different $\mathrm{pH}$ and total aluminium concentrations. Z Pflanzenernaehr Bodenkd 141: 741-751

Pietikäinen J, Kiikkilä O, Fritze H (2000) Charcoal as habitat for microbes and its effect on the microbial community of the underlying humus. Oikos $89: 231-242$

Salisbury FB, Ross CW (1985) Plant physiology, $3^{\text {rd }}$ edn. Wadsworth, Belmont 
1 Seiler W, Crutzen PJ (1980) Estimates of gross and net fluxes of carbon between the biosphere and the atmosphere from biomass burning. Climatic Change 2: 207247

Senapati BK, Lavelle P, Giri S, Pashanasi B, Alegre J, Decaëns T, Jimenez JJ, Albrecht A, Blanchart E, Mahieux M, Rousseaux L, Thomas R, Panigrahi PK, Venkatachalam M (1999) In-soil earthworm technologies for tropical agroecosystems. In: Lavelle P, Brussaard L, Hendrix P (eds) Earthworm management in tropical agroecosystems. CAB, London, pp 199-237

Skjemstad JO, Clarke P, Taylor JA, Oades JM, Mc Clure SG (1996) The chemistry and nature of protected carbon in soil. Aust J Soil Res 34: 251-271

Sparovek G (1998) Influence of organic matter and soil fauna on crop productivity and soil restoration after simulated erosion. Adv Geoecol 31: 431-434

Swift MJ (1977) The roles of fungi and animals in the immobilisation and release of nutrient elements from decomposing branch-wood. In Lohm U, Persson T (eds) Soil organisms as components of ecosystems. Ecol Bull 25: 193-202

Taiz L, Zeiger E (1998) Plant Physiology, $2^{\text {nd }} e d$. Sinauer, Sunderland

Tan KH (1982) Principles of soil chemistry. Dekker, New York

Tian G, Brussaard L, Kang B.T (1993) Biological effects of plant residues with contrasting chemical compositions under humid tropical conditions: effects on soil fauna. Soil Biol Biochem 25: 731-737

Tian G, Kang BT, Brussaard L (1997) Effect of mulch quality on earthworm activity and nutrient supply in the humid tropics. Soil Biol Biochem 29: 369-373

Titoff A (1910) Die Adsorption von Gasen durch Kohle. Z Phys Chemiestoch Verwandtschaftslehre 74: 641-678

Topoliantz S, Ponge JF (2003) Burrowing activity of the geophagous earthworm Pontoscolex corethrurus (Oligochaeta: Glossoscolecidae) in the presence of charcoal. Appl Soil Ecol 23: 267-271 
1 Topoliantz S, Ponge JF, Arrouays D, Ballof S, Lavelle P (2002) Effect of organic manure and the endogeic earthworm Pontoscolex corethrurus (Oligochaeta: Glossoscolecidae) on soil fertility and bean production. Biol Fertil Soils 36: 313-

4 319

5 Tryon EH (1948) Effect of charcoal on certain physical, chemical and biological 6 properties of forest soils. Ecol Monogr 18: 81-115

7 Voundi Nkana JC, Demeyer A, Verloo MG (1998) Availability of nutrients in wood ash 8 amended tropical acid soils. Environ Technol 19: 1213-1221

9 Wardle DA, Zackrisson O, Nilsson MC (1998) The charcoal effect in boreal forests: mechanisms and ecological consequences. Oecologia 115: 419-426

11 Zackrisson O, Nilsson MC, Wardle DA (1996) Key ecological function of charcoal from 12 wildfire in the Boreal forest. Oikos 77: 10-19.

13 


\section{Legends}

2

3 Fig. 1. Mean pod production of Vigna unguiculata sesquipedalis (yard-long bean)

4 according to treatments (M: manioc peel, Ch: charcoal, Sw: sawdust, NoA: non5 amended soil) with standard error. Numbers of replicates are shown in Table 2. Groups

6 significantly different are denoted by different letters. Kruskal-Wallis rank analysis $(\mathrm{H}=$ $7 \quad 18.5, \mathrm{P}<0.001$ ) was followed by a posteriori Dunn's tests.

8

9 Fig. 2. Mean densities of cocoons, juveniles and adults/subadults of the earthworm 10 Pontoscolex corethrurus according to treatments (4 replicates each) and in the natural 11 fallow (12 replicates), with standars errors. Treatment effects were compared by one12 way ANOVA (F). Significance of $F$ for each developmental category is indicated by $13{ }^{*} \mathrm{P}<0.05,{ }^{* \star} \mathrm{P}<0.001$. Groups significantly different are mentioned by different letters. 14 One-way ANOVA was followed by comparisons between amendments and natural 15 fallow using Dunnett contrasts. 
Table 1. Chemical composition of the different amendments (Topoliantz et al. 2002)

\begin{tabular}{|c|c|c|c|c|}
\hline & & $\begin{array}{l}\text { Manioc } \\
\text { peels }\end{array}$ & $\begin{array}{l}\text { Wood } \\
\text { charcoal }\end{array}$ & Sawdust \\
\hline $\mathrm{pH}\left(\mathrm{H}_{2} \mathrm{O}\right)$ & & 6.72 & 9.60 & 5.31 \\
\hline Ashes & $(\%)$ & 31.9 & 3.80 & 2.35 \\
\hline Total C & $\left(\mathrm{g} \cdot \mathrm{kg}^{-1}\right)$ & 356 & 905 & 521 \\
\hline Total N & $\left(\mathrm{g} \cdot \mathrm{kg}^{-1}\right)$ & 24.2 & 5.64 & 5.13 \\
\hline $\mathrm{C}: \mathrm{N}$ ratio & $\left(g \cdot \mathrm{kg}^{-1}\right)$ & 14.71 & 160 & 102 \\
\hline Total P & $\left(\mathrm{g} \cdot \mathrm{kg}^{-1}\right)$ & 2.26 & 0.27 & 0.06 \\
\hline Total K & $\left(\mathrm{g} . \mathrm{kg}^{-1}\right)$ & 10.3 & 5.05 & 0.35 \\
\hline
\end{tabular}


Table 2. Chemical soil composition of the initial soil in the upper $10 \mathrm{~cm}$ (means of 16 replicates \pm S.E.).

\begin{tabular}{|c|c|}
\hline $\mathrm{pH} \mathrm{H} \mathrm{H}_{2} \mathrm{O}$ & $4.75 \pm 0.05$ \\
\hline $\mathrm{pHKCl}$ & $3.84 \pm 0.03$ \\
\hline Total C $\left(\mathrm{g} \cdot \mathrm{kg}^{-1}\right)$ & $20.6 \pm 0.8$ \\
\hline Total N $\left(\mathrm{g} \cdot \mathrm{kg}^{-1}\right)$ & $1.34 \pm 0.04$ \\
\hline $\mathrm{C}: \mathrm{N}$ ratio & $15.3 \pm 0.3$ \\
\hline Total P (mg.kg ${ }^{-1}$ ) & $179 \pm 6$ \\
\hline Available $\mathrm{P}\left(\mathrm{mg} \cdot \mathrm{kg}^{-1}\right)$ & $17.3 \pm 4.8$ \\
\hline Total K (mg.kg $\left.{ }^{-1}\right)$ & $944 \pm 47$ \\
\hline Exchangeable $\mathrm{K}\left(\mathrm{mg} \cdot \mathrm{kg}^{-1}\right)$ & $2.52 \pm 0.22$ \\
\hline Exchangeable $\mathrm{Ca}\left(\mathrm{mg} \cdot \mathrm{kg}^{-1}\right)$ & $21.3 \pm 1.9$ \\
\hline Exchangeable $\mathrm{Mg}\left(\mathrm{mg} \cdot \mathrm{kg}^{-1}\right)$ & $10.8 \pm 1.2$ \\
\hline Exchangeable $\mathrm{Na}\left(\mathrm{mg} \cdot \mathrm{kg}^{-1}\right)$ & $0.69 \pm 0.08$ \\
\hline Exchangeable Al $\left(\mathrm{mg} \cdot \mathrm{kg}^{-1}\right)$ & $7.97 \pm 0.91$ \\
\hline $\operatorname{CEC}\left(\mathrm{cmol}_{C} / \mathrm{kg}\right)$ & $2.48 \pm 0.08$ \\
\hline Base saturation (\%) & $55.7 \pm 3.9$ \\
\hline
\end{tabular}

2 
Table 3. Biological parameters of Vigna unguiculata sesquipedalis according to treatments (M: manioc peels, Ch: charcoal, Sw: sawdust, NoA: non-amended soil). Effects of treatments were tested by one-way ANOVA (F) or Kruskall-Wallis rank test $(H)$. Significance levels are indicated by ${ }^{*} P<0.05,{ }^{* \star} P<0.01,{ }^{* \star *} P<0.001$, N.S. not significant. Groups significantly different according to a posteriori multiple comparisons are denoted by different superscript letters. All weights and ratios are based on dry weights of plant parts

\begin{tabular}{lllllll}
\hline & $\mathrm{M}+\mathrm{Ch}$ & $\mathrm{M}+\mathrm{Sw}$ & $\mathrm{Ch}+\mathrm{Sw}$ & $\mathrm{M}+\mathrm{Ch}+\mathrm{Sw}$ & $\mathrm{NoA}$ & Tested statistics \\
\hline Number of shoots & 9 & 7 & 7 & 5 & 13 & \\
Shoot weight (g dry wt) & $7.08 \pm 1.92^{\mathrm{a}}$ & $7.43 \pm 1.51^{\mathrm{a}}$ & $3.92 \pm 0.83^{\mathrm{a}}$ & $5.76 \pm 2.42^{\mathrm{a}}$ & $0.64 \pm 0.08^{\mathrm{b}}$ & $\mathrm{F}=18.6^{\star \star \star}$ \\
Shoot:root ratio (wt:wt) & $7.92 \pm 0.52^{\mathrm{a}}$ & $8.12 \pm 0.69^{\mathrm{a}}$ & $7.78 \pm 1.34^{\mathrm{a}}$ & $8.73 \pm 1.17^{\mathrm{a}}$ & $3.84 \pm 0.35^{\mathrm{b}}$ & $\mathrm{F}=9^{* \star *}$ \\
Pod production:shoot ratio (wt $0.31 \pm 0.08^{\mathrm{a}}$ & $0.11 \pm 0.08^{\mathrm{ab}}$ & $0 \pm 0^{\mathrm{b}}$ & $0.07 \pm 0.03^{\mathrm{ab}}$ & $0.08 \pm 0.04^{\mathrm{ab}}$ & $\mathrm{H}=14.3^{* \star}$ \\
Pod production:root ratio (wt: $2.39 \pm 0.61^{\mathrm{a}}$ & $0.95 \pm 0.63^{\mathrm{ab}}$ & $0 \pm 0^{\mathrm{b}}$ & $0.67 \pm 0.28^{\mathrm{ab}}$ & $0.24 \pm 0.13^{\mathrm{b}}$ & $\mathrm{H}=17.9^{\star \star \star}$ \\
Shoot:nodule ratio (wt:wt) & $2409 \pm 823^{\mathrm{a}}$ & $1046 \pm 373^{\mathrm{ab}}$ & $1300 \pm 891^{\mathrm{ab}}$ & $712 \pm 395^{\mathrm{ab}}$ & $384 \pm 82^{\mathrm{b}}$ & $\mathrm{H}=13.9^{\star *}$ \\
Root:nodule ratio (wt:wt) & $295 \pm 101$ & $154 \pm 64$ & $126 \pm 59$ & $90.9 \pm 59.9$ & $98.8 \pm 17.7$ & $\mathrm{H}=9$ N.S. \\
\hline
\end{tabular}


Table 4. Nutrient contents of the soil at the end of the trial according to treatments (means of 11 samples \pm SEM). Otherwise as for Table 2.

\begin{tabular}{|c|c|c|c|c|c|c|}
\hline & $\mathrm{M}+\mathrm{Ch}$ & $\mathrm{M}+\mathrm{Sw}$ & $\mathrm{Ch}+\mathrm{Sw}$ & $\mathrm{M}+\mathrm{Ch}+\mathrm{Sw}$ & NoA & Tested statistics \\
\hline $\mathrm{pH} \mathrm{H}_{2} \mathrm{O}$ & $4.88 \pm 0.03^{\mathrm{a}}$ & $4.62 \pm 0.05^{b}$ & $4.810 .06^{\mathrm{a}}$ & $4.88 \pm 0.04^{a}$ & $4.40 \pm 0.04^{c}$ & $\mathrm{~F}=21.3^{\star \star \star}$ \\
\hline $\mathrm{pH} \mathrm{KCl}$ & $4.00 \pm 0.04^{\mathrm{a}}$ & $3.74 \pm 0.02^{\mathrm{cd}}$ & $3.84 \pm 0.03^{b c}$ & $3.87 \pm 0.02^{b}$ & $3.67 \pm 0.02^{d}$ & $\mathrm{~F}=21 \cdot 3^{\star \star \star}$ \\
\hline Total C $\left(\mathrm{g} \cdot \mathrm{kg}^{-1}\right)$ & $21.4 \pm 1.2^{\mathrm{bc}}$ & $29.1 \pm 2.2^{\mathrm{ab}}$ & $26.0 \pm 2.8^{\mathrm{abc}}$ & $32.5 \pm 3.2^{\mathrm{a}}$ & $19.6 \pm 0.6^{c}$ & $\mathrm{~F}=5.8^{\star \star \star}$ \\
\hline Total N $\left(\mathrm{g} \cdot \mathrm{kg}^{-1}\right)$ & $1.27 \pm 0.08^{\mathrm{ab}}$ & $1.45 \pm 0.06^{\mathrm{a}}$ & $1.07 \pm 0.05^{\mathrm{b}}$ & $1.36 \pm 0.07^{\mathrm{a}}$ & $1.46 \pm 0.03^{\mathrm{a}}$ & $\mathrm{F}=7.7^{\star * *}$ \\
\hline C:N ratio & $16.6 \pm 0.4^{\mathrm{bc}}$ & $19.9 \pm 1.1^{\mathrm{ab}}$ & $23.8 \pm 1.7^{\mathrm{a}}$ & $23.5 \pm 1.5^{\mathrm{a}}$ & $13.4 \pm 0.1^{c}$ & $\mathrm{H}=37.2^{\star \star \star}$ \\
\hline Total P (mg.kg $\left.{ }^{-1}\right)$ & $171 \pm 11^{\mathrm{ab}}$ & $175 \pm 7^{\mathrm{ab}}$ & $159 \pm 21^{b}$ & $167 \pm 8^{\mathrm{ab}}$ & $212 \pm 15^{a}$ & $H=16.8^{* *}$ \\
\hline Available P (mg.kg $\left.{ }^{-1}\right)$ & $14.9 \pm 0.7^{\mathrm{bc}}$ & $17.6 \pm 0.8^{\mathrm{ab}}$ & $13.0 \pm 0.7^{c}$ & $18.1 \pm 0.8^{\mathrm{a}}$ & $15.0 \pm 0.5^{\mathrm{bc}}$ & $\mathrm{F}=9^{\star \star \star *}$ \\
\hline Total K (mg.kg $\left.{ }^{-1}\right)$ & $736 \pm 31^{b c}$ & $836 \pm 39^{b}$ & $673 \pm 41^{c}$ & $891 \pm 58^{b}$ & $1091 \pm 28^{a}$ & $\mathrm{~F}=15.7^{\star \star \star}$ \\
\hline Exchangeable $\mathrm{K}\left(\mathrm{mg} \cdot \mathrm{kg}^{-1}\right)$ & $2.67 \pm 0.20^{b}$ & $5.05 \pm 0.33^{\mathrm{a}}$ & $2.59 \pm 0.30^{b}$ & $4.66 \pm 0.45^{\mathrm{a}}$ & $2.20 \pm 0.11^{b}$ & $\mathrm{~F}=21.2^{\star \star \star}$ \\
\hline Exchangeable $\mathrm{Ca}\left(\mathrm{mg} \cdot \mathrm{kg}^{-1}\right)$ & $24.4 \pm 1.3^{\mathrm{a}}$ & $15.5 \pm 0.6^{b}$ & $17.7 \pm 0.6^{\mathrm{b}}$ & $16.5 \pm 1.0^{\mathrm{b}}$ & $16.4 \pm 1.6^{\mathrm{b}}$ & $\mathrm{F}=10.3^{* * *}$ \\
\hline Exchangeable $\mathrm{Mg}\left(\mathrm{mg} \cdot \mathrm{kg}^{-1}\right)$ & $4.59 \pm 0.37^{\mathrm{ab}}$ & $4.99 \pm 0.36^{a}$ & $3.49 \pm 0.27^{b}$ & $4.31 \pm 0.26^{\mathrm{ab}}$ & $2.23 \pm 0.14^{\mathrm{c}}$ & $\mathrm{F}=14^{\star \star *}$ \\
\hline Exchangeable $\mathrm{Na}\left(\mathrm{mg} \cdot \mathrm{kg}^{-1}\right)$ & $0.77 \pm 0.06$ & 0.730 .04 & $0.69 \pm 0.07$ & $0.73 \pm 0.09$ & $0.56 \pm 0.06$ & $\mathrm{~F}=1.9 \mathrm{~N} . \mathrm{S}$ \\
\hline Exchangeable Al (mg. $\left.\mathrm{kg}^{-1}\right)$ & $3.84 \pm 0.23^{c}$ & $6.34 \pm 0.41^{\mathrm{b}}$ & $4.98 \pm 0.32^{\mathrm{bc}}$ & $5.79 \pm 0.61^{b}$ & $12.7 \pm 0.6^{\mathrm{a}}$ & $\mathrm{F}=60.2^{\star \star \star}$ \\
\hline CEC $\left(\mathrm{cmol}_{C} / \mathrm{kg}\right)$ & $2.42 \pm 0.11^{\mathrm{ab}}$ & $2.53 \pm 0.08^{\mathrm{ab}}$ & $2.17 \pm 0.09^{b}$ & $2.31 \pm 0.13^{b}$ & $2.71 \pm 0.08^{a}$ & $\mathrm{~F}=4.2^{* *}$ \\
\hline Base saturation (\%) & $70.0 \pm 1.6^{\mathrm{a}}$ & $53.6 \pm 1.9^{b}$ & $58.6 \pm 1.8^{b}$ & $58.8 \pm 3.3^{b}$ & $39.6 \pm 2.3^{c}$ & $\mathrm{~F}=23.3^{* * *}$ \\
\hline
\end{tabular}

2 


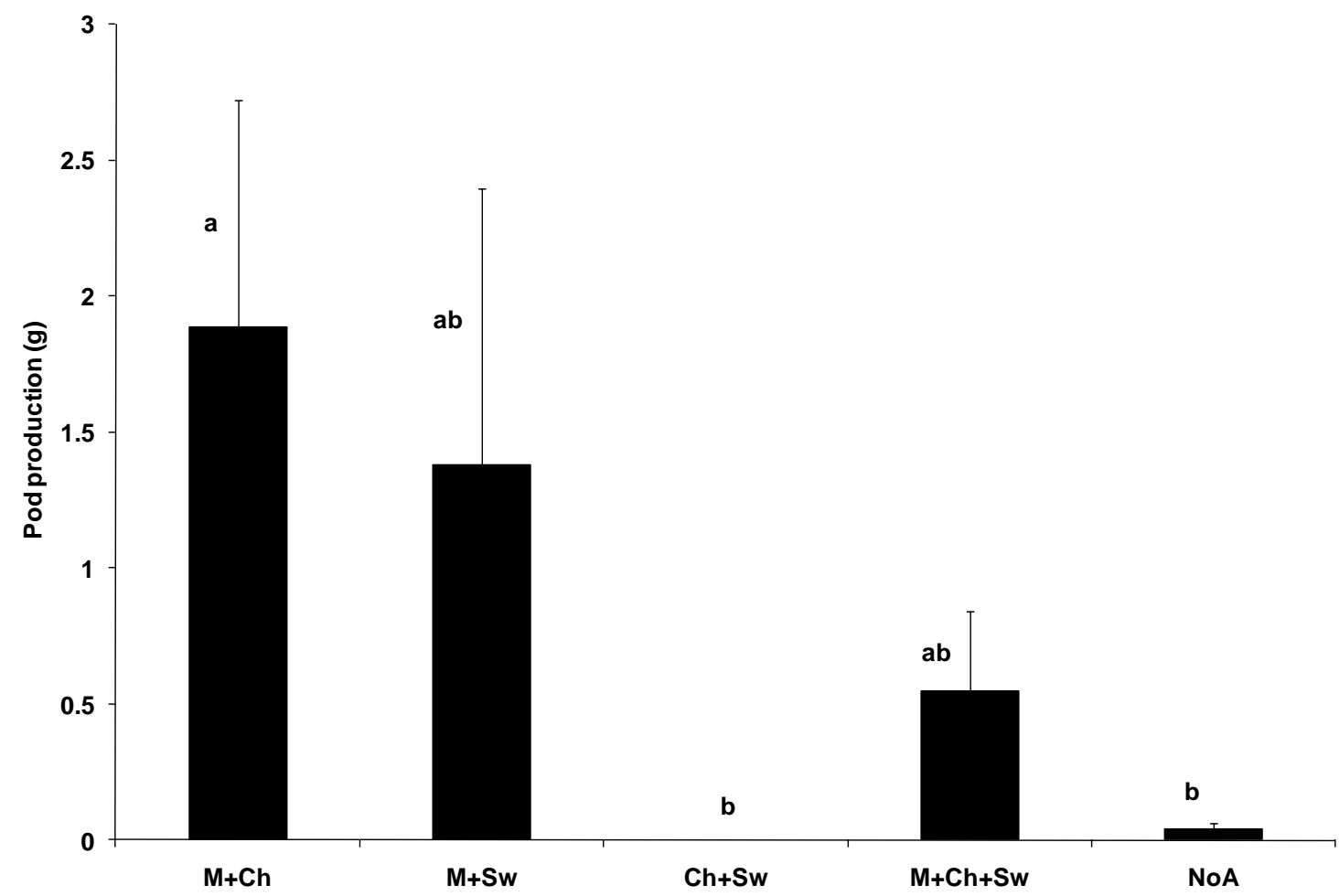

2 Fig. 1 


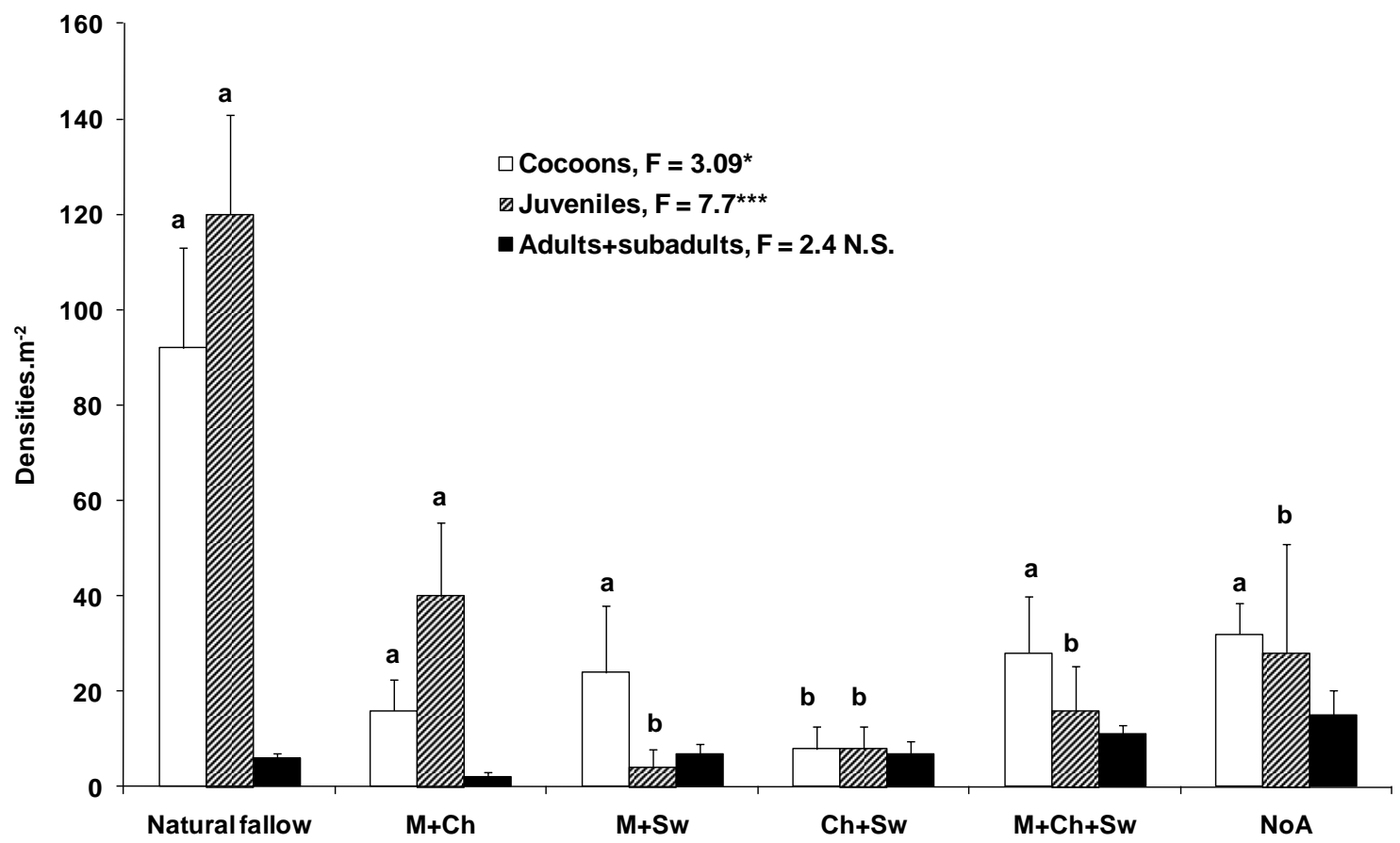

2 Fig. 2 